\title{
The Topographical Changes Performed in the Holy Shrines of Bukhara City
}

Jurayeva Nafisa Olimovna

Senior Lecturer, Bukhara State University, Bukhara, Uzbekistan.Email: n.o.jurayeva@buxdu.uz

Copyright: (๑) 2021 Jurayeva Nafisa Olimovna. This is an open access article distributed under the terms of the Creative Commons Attribution License, which permits unrestricted use, distribution, and reproduction in any medium, provided the original author and source are credited.

The following article analyses the specific historical topographical path of the development of the cemeteries of the city of Bukhara and the changes made in them. Also, answers to such questions as whether the holy places influenced the expansion of the territory of the city of Bukhara or vice versa, whether they influenced the preservation of the city in a certain territorial volume are provided in detail. The traditions of the topographical changes are reconsidered based on the diverse historical sources.

Keywords: Shrine, Holy sites, Places of pilgrimage, Cemetery, Border, Topography, Territorial changes.

\section{Introduction}

Bukhara is an important pilgrimage destination in Uzbekistan. In Bukhara, there are many pilgrimage and holy shrines of the great thinkers which are important objects of Tourism. Therefore, when our President Sh.M. Mirziyoyev every time visits Bukhara, they first of all call for the productive use of this opportunity of Bukhara Sharif. In this regard, it is appropriate to note that the research on the holy shrines of the city of Bukhara is also an important component of the reforms carried out in this direction.

The issue of the topography of the sacred shrines of Bukhara city has always been one of the topics in the focus of the researchers. There is also a specific historical topographic development of the Bukhara city temples, this development occurred directly in connection with the construction, reconstruction of the walls of the city of Bukhara, the change of its individual parts and the process of moving some of its parts. Because, in most cases, Graves are found outside the city walls. Naturally, as a result of the demographic growth of the population, the city grew. Were the sacred shrines taken into account when building a defensive wall in the extended part of the city, tried not to interfere them, did the sacred shrines influence the unextended of the city, or rather, to preserve it in a certain territorial size?

\section{Main Part}

In order to ensure the security of the extended part of the city, in years 849-850, after the first wall of Rabat in Bukhara, another outer wall was built, which surrounded Rabat, Ark and Shahristan in a circle [3]. So, Bukhara is surrounded by a ring of single outer wall, which also includes three parts of the old one. The researchers note that within this wall the city was 5 times larger than at the beginning of the $8^{\text {th }}$ century [2]. So it is natural, of course, that in this place the city has grown in size, which justified the question of what certain tombs remained inside the city and outside the wall.

Sources indicate that during this period inside the wall in the city of Bukhara is located the Tomb of Khoja Nurabad, the Tomb of the legendary King Siyavush. With the passage of the periods, the construction carried out in 
the Ark did not bypass the Siyavush tomb, which was raised among the people as a governor. By the middle of the $18^{\text {th }}$ century, during the Manghit dynasty, when the eastern side of the Ark was turned into a citadel of Amirs, the gate "Davozai Guriyan" was plunged, leaving a single gate, a gate Registan. The Tomb of Siyavush was also moved from the ancient Guriyan gate to the gate of Registan, to the bottom of The Naghorakhona.

By order of the Manghit emirs, they build and breed the symbolic grave of Siyavush in a special cell there. Those who came to visit went upstairs through special stairs on the right side when they entered the gate of Registan and visited the tomb of Siyavush. The pilgrims were barred from the way through the Palace of Emir and its place [6],[15]. Thus, measures have been taken to prevent the flow of pilgrims from disrupting the activities of Amir and officials in the public administration. In the time of the great creative work continued. As a result, in the IX-X centuries outside the walls of the city of Bukhara there were Khoja Solor, outside the Darvozai Maydana there was a large churchyard, the famous tomb of Ismail Samani, the scholar of Islamic legislation Abu Hafs Kabir Bukhari The Bukhara Rabat, which has become an important part of the city, is surrounded by a defensive wall consisting of 11 gates. It is noted by many researchers that the first wall of the rabad was not preserved, but the boundaries of the second wall of the rabad and its eleventh Gates can be stretched along the ring of the old cemeteries, which are located within the present city and are outside the gates of the first wall of the rabad [3]. On the historical-topographic maps, where the boundaries of the city and the city wall of this period are reflected, one can see that many tombs are located outside the city walls.

In the Middle Ages, social life in the city continued, and over time the area of the city became more and more. Around it, outside the city wall, new topographic objects: puddles, guzar and neighborhoods have raised the kamen. This in turn led to the need to surround the city with another wall. During this period, the Uzbek Khans were engaged in the reconstruction of the city Abdulazizkhan (1504-1549), then Abdullakhan (1557-1598). Abdulazizkhan, in his time, built new walls of Rabat. Its walls fall within the boundaries of the city wall of the last centuries, not counting the western part, which goes from the Khoja (Hodjiyon) gate to the North.

Sources emphasize the fact that during the reign of Sheikh Abdullakhan of the 16th century the city of Bukhara was established for some time, by the decree of the Khan the city wall and military fortifications were rebuilt, as well as madrasahs, caravanserais and new stalls were restored in the city, Tim (Timi-Abdullakhan) on the trade routes between the cities, domes, baths, The western part of the wall of Abdulazizkhan was demolished by Abdullahan and a project was established in place. The new wall was pushed to the west, to the borders of the last wall (19 century), including the Houses of the powerful fur sheiks inside the city. The gates of Sheikh Jalal, Karakul, Shirgaran and Talipoch were built [3].

The gate of Sheikh Jalal was preserved with mosaic decoration of the $16^{\text {th }}$ century, the remaining gates were repeatedly repaired. After the city was surrounded by another defensive wall, the tombs of Khoja Ghunjari, Sheikh Jalal, Sheikh Rangrez were located inside the wall. Khoja Solor, who was outside the wall of Bukhara in the $9^{\text {th }}$ century, a large churchyard outside the gate of The Square, the famous Ismaili shrine, the fiqhshunos scholar Abu Hafs Kabir Bukhari during this period now settled inside the city wall, that is, during the construction of the defensive wall in the kengaygan part of the city, holy shrines were taken into account, they Thus, the architectural 
image of Bukhara in the $19^{\text {th }}$ century was formed mainly in the $16^{\text {th }}$ century. It is also written about the facts that during these period 11 gates were entered into the city, as well as each guzar had its own cemetery.

\section{Results}

It is noted that by the beginning of the $20^{\text {th }}$ century in Bukhara there were 17 cemeteries within the city walls, in the market and residential areas, and seven more cemeteries outside the wall.

Scientific sources say that the Turki-Jandi Cemetery in the city the graves were placed one above the other, and since there are several floors, the tombs made of "Saghana" are only left in the air, and thousands of graves are adjacent to the places where people live [3].

And during the time of the former Union, many holy shrines and cemeteries were destroyed because of anti-religious policies, which were allocated to the local population for housing. For example, Tali Ghariban cemetery where many progressives buried in the city of Bukhara was destroyed under the pretext of market construction in the 1980s [6]. Also, mausoleums and tombs of famous poets and scientists were destroyed.

Hundreds of rare architectural monuments such as the tomb and mausoluem of the famous poet Abdurahman Mushfiqi of the $16^{\text {th }}$ century, the Mausoleum in Khoja Ubon ( $14^{\text {th }}$ century), the Khoja Ismat mausoleum $\left(15^{\text {th }}\right.$ century) were demolished [6].

The mausoleum of Abu Bakri Is'haq Kalobodi, a well-known Islamic jurisprudence scholar of the $10^{\text {th }}$ century, and the churchyard around him were also not excluded from this policy. In this cemetery, located next to the "Darvozai mozor" in Bukhara, Abu Bakri Is'hak Kalabadi, the Mausoluem of dozens of Bukhara's major scholars, such as the scientist, poet Ahmad Donish, who lived in the second half of the $19^{\text {th }}$ century, and the bastions consisting of 15 layers, were completely leveled with the land, and they were given lots of residences [6],[4]. In the Middle Ages, the area of Turki Jandi cemetery, which is located in the south-west of Bukhara and is the largest cemetery in the city, was reduced and a kindergarten was built in its place. The Tomb of khaliph Khudoydad, a rare architectural monument of Bukhara, the Mausoleum of Sardoba ( a healing fountain over which it was closed), the tomb , the mausoleum of Eshoni imlo, the mosque, the graves of some of the emirs of Bukhara were leveled with the Earth and the school and private residential areas were built instead [6],[4]. In the 1950s, this policy was continued again, the local party and Soviet leaders, under the pretext of fighting against religion, broke the Afrosiab Hill and made their way: the Tomb of Abu Hafs Kabir, mausoleums of the Sufis scholars and other architectural monuments were demolished [6],[12]. As a result of such territorial changes carried out with the issue of expanding the city of Bukhara, the outstanding manifestations of our national spirituality and their activities have led to the oblivion of our people.

\section{Conclusion}

In conclusion, in the Middle Ages in the extended part of the city of Bukhara, every time a new defensive wall was built, the holy shrines were taken into account, new puddles, guzars and neighborhoods were erected around this holy shrine, and the holy shrines became the topographical composition of the city on the basis of the formation of the city's territory and during the Soviet Union, some holy shrines and cemeteries were demolished under the 
pretext of building social and household buildings, in place of which were built settlements of population. Topographic research of the destroyed and forgotten sacred shrines is an important task in the future, which is connected with the process of studying the activities of the great ones there, at least in the same place installing a symbolic monument to them, restoring their memory and studying their scientific heritage.

\section{Declarations}

\section{Source of Funding}

This research did not receive any grant from funding agencies in the public, commercial, or not-for-profit sectors.

\section{Competing Interests Statement}

The author declares no competing financial, professional and personal interests.

\section{Consent for publication}

Author declares that he/she consented for the publication of this research work.

\section{Availability of data and material}

Author is willing to share relevant data and materials according to the relevant needs.

\section{References}

[1] Jurayeva Nafisa Olimovna, (2019). Features of the Historical Topography of the City of Bukhara. Test Engineering \& Management, C.1356-1360.

[2] Abu Bakr Muhammad ibn Ja'far Narshaxiy Buxoro tarixi/fors-tojik tilidan A. Rasulev tarjimasi. -Toshkent: Shark bayozi (1993).

[3] Belenitskiy, A.M., Bentovich, I.B., Bolbshakov, O.G. Srednevekoviy gorod Sredney Azii.-L.: Nauka, (1973).

[4] Rempelь, L.I., Dalyokoe i blizkoe zapisы-Stranitsy jizny, bыta, stroitelnogo dela, remesla i isskustva Staroy Buxary.-T.:Gafur Gulyam, (1982).

[5] Suxareva, O.A., Kvartalnaya obshina pozdnefeodalınogo goroda Buxarb.-Moskva.: Nauka, (1976).

[6] Umnyakov, I.I., K voprosu ob istoricheskoy topografii srednevekovoy Buxar» (sbornik Turkestanskogo Vostochnogo instituta, v chest prof. A. S. Shmidta, Tashkent, (1923).

[7] Yo'ldoshev N. Buxorodagi ayrim avliyolar tarixi.-Buxoro.:Buxoro, (1993).

[8] Jo'raeva N.O., Buxoro shahri tarixiy topografiyasining shakllanishida muqaddas ziyoratgohlarning o'rni.-Xiva.://Vestnik Xorezmskoy akademii Ma’muna, (2019).

[9] Akbar, J., (1988). Crisis in the built environment: The case of the Muslim city. Concept Media.

[10] Turdiyev, B.S., The role of national harmony in the strategy of spiritual renewal. Scientific Bulletin of Namangan State University (2019). 
[11] Sobirovich, T.B., Strategy of Renewal of National Spirituality of Uzbekistan. International Journal on Integrated Education, (2020) 122-126.

[12] Sobirovich, T. B., Murodogli, I. S., The strategy for the implementation of the modern governance system in Uzbekistan. ACADEMICIA: An International Multidisciplinary Research Journal, (2020) 741-748.

[13] Sobirovich, T.B., Strategy of spiritual renewal in Uzbekistan. International Journal of Psychosocial Rehabilitation, (2020).

[14] Sobirovich, T. B., The criterion of human indicators in development and renewals in Uzbekistan. EPRA International Journal of Multidisciplinary Research, (2020) 509-511.

[15] Sobirovich, T.B., O"zbekiston demokratik jamiyat taraqqiyoti rivojida ma" naviy yangilanishlar strategiyasining roli. Imom Buxoriy saboqlari, (2020) 118-121.

[16] Sobirovich, T.B., The Strategy of Cultural Development in Central Asia During Amir Temur and the Temurids Dynasty, Int. J. Sci. Res. in Multidisciplinary Studies, (2021).

[17] Sobirovich, T.B., The Strategy of Cultural Development in Central Asia during Amir Temur and Temurids Dynasty Reign, Irish Interdisciplinary Journal of Science \& Research, (2021) 18-22.

[18] Sobirovich, T.B., Evolution of ideas and views on the development of democratic society and spiritual renewals. Scientific Bulletin of Namangan State University, 243-250.

[19] Sobirovich, T.B., Tourism in Central Asian context, Вестник Института/Сокровищница Науки, (2019) $732-733$.

[20] Sobirovich, T.B., The national and universal principles of democracy in the Central Asian context. International Journal of Advanced Research and Review, (2021) 30-34.

[21] Turdiyev, B.S., Cultural and educational development of society in the scientific heritage of world philosophers. Academic research in Educational Sciences, (2021) 443-451.

[2] Sobirovich, T.B., Sharipovna, A.F., New uzbekistan-new strategy of administrative reforms, researchgate.net.

[23] Sobirovich, T.B., Ma'naviy yangilanishlar strategiyasining hayotbaxsh islohotlari: nazariya va amaliyot, O’zbekiston Milliy axborot agentligi-O’zA Ilm-fan bo'limi (elektron jurnal), Tashkent, 1-12.

[24] Turdiev, B. S., Saidjonova Z.S., Ancient and modern Bukhara, Экономика и социум. (2019) 117-119.

[25] Turdiyev Bexruz Sobirovich, Ma'naviy yangilanish: yangi qaror va hayotbaxsh islohotlar strategiyasi. Buxoro davlat universiteti Ilmiy axboroti. Buxoro, (2018) 208-213.

[26] Turdiyev, B., The contribution of bobur and boburi dynasty to the renewal of world civilization. Центр Научных Публикаций (buxdu.uz), (2021).

[27] Turdiyev, B., Behbudi's views on the spiritual renewal of society. Центр Научных Публикаций (buxdu.uz). (2021). 
[28] Turdiyev, B. Sharq VA G 'ARB Mutafakkirlari qarashlarida jamiyat taraqqiyoti ma'naviy yangilanishlar mezoni. Центр научных публикаций (buxdu.uz), (2021).

[29] Sobirovich, T.B., Spirituality and its Need for Human Life. Online-Conferences" Platform, (2021).

[30] Turdiyev, B., Confucius's views on spiritual renewal. Центр Научных Публикаций (buxdu.uz), (2021).

[31] Turdiyev, B., Spiritual Renewal: THE new decree and the strategy of life-inspiring reforms. Центр Научных Публикаций (buxdu.uz), (2021).

[32] Turdiyev, B., Bukhara-center of islamic spiritual and culture. Центр Научных Публикаций (buxdu.uz), (2021).

[33] Turdiyev, B., Behbudi's views on the spiritual renewal of society, Центр Научных Публикаций (buxdu.uz), (2021). 